\title{
Descentralização: única saída?
}

\section{Mauro J. ferraz Lopes (*)}

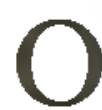
ciclo do autoritarismo acabou $\mathrm{e}_{\text {, }}$ com isto, desperta a Nação para novo ciclo de ampla participação democrática. Natural, pois, que se busque reverter tudo o que poderia significar cerceamento de liberdades ou manifestaçāo de poder oligárquico. Se o ciclo anterior era centralizado, natural é dcsejar o pólo oposto e caminhar para a descentralizaçāo. Mas será esse, realmente o caminho ideal para resolver os grandes problemas brasileiros?

A centralização do poder não é característica exclusiva dos regimes autoritários, nem derivou, no Brasil, do regime adotado nos últimos vinte anos. Na verdade, desde os tempos da Colônia e do Império, passando pela República, o Brasil é centralizado. A Federaçāo amenizou um pouco a cenIralizaçāo, mas o País jamais esqueceu que nasceu unitário e, até hoje, mantém suas anteriores tradiçōes, em face da cultura de nossa gente, herdada de rossos antepassados. No mundo moderno tem ocorrido fenômeno inverso. Os Estados Unidos da América - exemplo de democracia
- nasceram federaçāo, mas, a cada dia, a Uniāo fica mais íorte e assume maior poder, ampliando suas funções e atribuições e relegando os Esados a um plano politicamente inferior, LESLIE LIPSON, proíessor de Berkeley, assegura que a tendência indiscuintegrar e centralizar. E justifica: "O anseio político em favor da igualdade de direitos e de maior equanimidade no tratamento das pessoas; a extensāo dos mercados, com a crescente padronizaçāo dos produlos e a uniformidade dos gostos; a busca da segurança social e da estabilidade econômica; as tensōes que impōem a preparação militar e a lecnologia da guerra numa era de propulsão a jato, foguetes espaciais e energia atômica - todas essas condições nāo se coadunam com a separação de poderes e o dispersar de atribuiçōes. Diferentes esferas de governo já nāo poderão ser consideradas independentes, em seus respectivos âmbitos. Cada uma delas depende das demais, ou melhor, sāo todas interdependentes".

Além disso, a descentralização do poder envolve o grande risco de criar

:-' Mauro J Ferraz Lopes é promoror de Jusiç̧a no Estado do Rio de Janeiro e ex-assessor do Programa Nacional de Desburocranizaça

ou gerar a desordem e a desunião nacional, pondo em risco, inclusive, a democracia, especialmente se inexistirem, nas esferas locais, organismos democráticos bem estruturados para - exercício do poder que lhes for transferido. Tais organismos são, essencialmente, os Partidos Políticos, porquanto, nas democracias, é através deles que o poder é efetivamente exercido. Sem perfeita estruturação dos partidos políticos locais, a descentralização poderá resultar na ditadura local, exercida pelos déspotas ou tiranos de fonteira, cuja independência desafiará o governo central ou as liberdades por ele organizadas, sem qualquer benefício para a nação, em seu lodo, ou para a população local.

É inegável, todavia, que a descentralização traz inúmeras vantagens, como a Desburocratizaçāo do Estado, pelo desmantelamento do seu gigantismo com a criação de diversas entidades estatais menores, que terão gerência mais fácil e maior controle popular, as quais servirāo também de escola para os administradores públicos, preparando-os para governar as entidades maiores, onde aplicarāo, na esfera nacional, a experiência adquirida no âmbito local.

Não se busque, entretanto, a descentralizaçāo por motivos simplesmente emocionais, como decorrência de impensada reação ao centralismo anterior, causado, apenas em parce, pelo autoritarismo. Governos centralizados podem coexistir com a demo- 


\section{IDÉIAS}

cracia perfeita, e exemplos disso nảo faltam no mundo. Evidentemente, o que é inadmissivel é o centralismo exagerado, ou excessivo. Extrema sunt viciosa, virtus in medio est. Temperese o excesso e a federação brasileira ficará fortalecida e aperfeiçoada, sem se cair no exagero oposto e reduzir além dos limites, o poder central. E sempre necessário lembrar que a centralização das decisões normativas ou das diretrizes governamentais não impede que se descentralize a execução de tais decisões, desde que as normas ou diretrizes levem em conta a grande variedade das situações reais encontradas nas regiões ou localidades de características bem diferentes, umas das outras. Em certas ocasiões, melhor do que descentralizar é desconcenlrar, porque, pela desconcentraçảo, ganham-se as vantagens da descentralização, sem se correr os grandes riscos dela decorrentes. Tais riscos, à evidência, são ponderáveis porque, se o País já vive a democracia real, as instituiçōes democráticas brasileiras, com ênfase especial para os partidos políticos, estão ainda em fase de transição, para seu aperfeiçoamento completo.
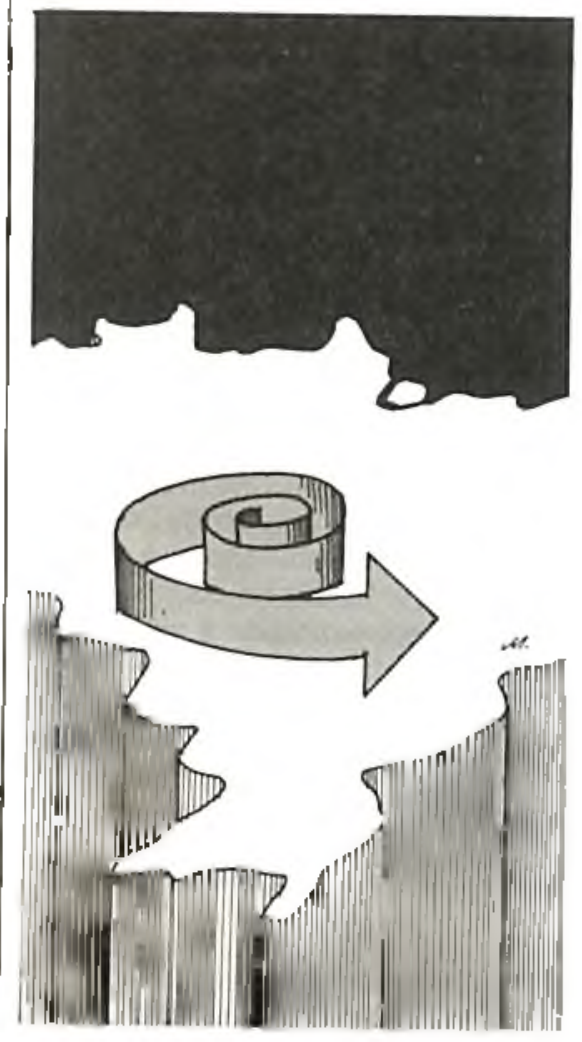

\section{A Universidade no apoio à Reforma}

\section{José Raymundo Martins Romêo (*)}

$\mathrm{R}$ eformar é conseqüência natural do processo de mudanças sociajs e do avanço técnico-científico que interagem na sociedade. Em decorrência, crescem a demanda e as exigências qualitativas na prestação de serviços público.

A administraçāo buscou na teoria sistêmica absorver essas influências e resgatá-las, dotando o complexo organizacional da necessária nexibilidade. Na prática, no entanto, é difícil implantar mudanças quando às facilidades tecnológicas disponiveis se contrapõem heranças e disfunções adquiridas ao longo da incorporação à administração pública de vícios congênitos, como a prevalência circunstancial do mérito, excessiva burocracia, insatisfaçāo salarial, diversidade de regimes juridicos, soluçōes de continuidade dos projetos saneadores, etc.

O exame dessa conjuntura, complexa por excelência, evidencia a necessidade de mobilizaçāo de conhecimento multidisciplinares. Por essa razāo, é justo ressaltar a clarividência do Ministro da Administraçāo, Aluízio Alves, ao propor o engajamen-

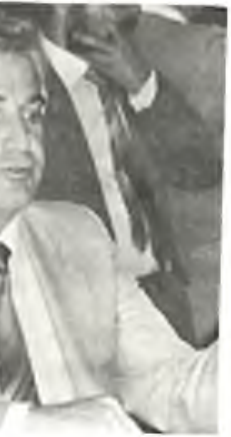

to do potencial das Universidades no esforço para sanear a administraçảo pública federal e lhes assegurar efetividade no desempenho da nobre missão de servir ao usuário dos serviços públicos.

Em abono da competência e da propriedade da mobilização das ofjcinas de trabalho intelectual e instrumental disponivel nas Instituiçôes de Ensino Superior (IES), podemos citar: a) situam-se em todas as unidades da Federaçāo e sob diferentes matizes culturais e organizacionais, desde instituiçōes públicas e privadas até a opçāo por áreas de excelência; b) dispōem de recursos humanos, instalações e equipamentos capazes de, a curto prazo, produzir diagnósticos, multiplicar as experiências de treinamento e implementar e avaliar as mudanças; c) possuem aguçada consciência crítica, de modo que o Ministério da Administração passaria a dispor de permanente ótica realista do desempenho das ações implementadas, recebendo, ao mesmo tempo, críticas e sugestōes objetivas quanto aos resultados alcançados.

Com a Nova República, os brasipresidenle do Conselho de Reilores das Universidades Brasıleiras 